
June 1939

\title{
EFFECTS OF METHIONINE, DJENKOLIC ACID, AND BENZYLCYSTEINE ON THE ESTIMATION OF CYSTINE BY THE DROPPING MERCURY CATHODE
}

\author{
By Edgar Reynolds Smith and Clement James Rodden
}

\begin{abstract}
The reduction maximum of cysteine at the dropping mercury cathode, in a buffered solution containing bivalent cobalt, is not affected by methionine or benzylcysteine at concentrations up to somewhat more than twice that of the cysteine. Djenkolic acid reduces the height of this maximum without changing its form or position. By themselves, methionine, benzylcysteine, and djenkolic acid show no reduction wave between 0.8 and $2.1 \mathrm{v}$.
\end{abstract}

\section{CONTENTS}

I. Introduction

II. Apparatus and materials

III. Experimental results... 670

\section{INTRODUCTION}

The determination of cystine or cysteine by means of the polarograph is made in a buffered solution containing a bivalent cobalt salt and is considered to depend upon a catalytic reduction of hydrogen from the sulfhydryl group of the organic complex compound, formed with the cobalt, which produces a characteristic maximum on the current-voltage curve. ${ }^{1}$ This method has been used for the estimation of cystine in hydrolysates from protein materials, such as wool ${ }^{2}$ and insulin, ${ }^{3}$ at concentrations as low as $10^{-6} \mathrm{~g} / \mathrm{ml}$ of cystine. Under the environmental conditions of the determination, the curve obtained is apparently characteristic of the sulfhydryl group, or of the disulfide group if the latter is first reduced to the sulfhydryl group, at the dropping mercury cathode. Thus, Brdicka found that thioglycolic acid, glutathione, cysteyl-glycine, and an uncertain decomposition product of $\beta \beta^{\prime}$-dichloroethyl sulfide (mustard gas) ${ }^{4}$ exhibit a similar behavior, whereas no such effect is shown by the amino acids glycocoll, asparagine, creatine, creatinine, arginine, leucine, and tyrosine, which do not contain sulfhydryl. Sladek and Lipschutz ${ }^{5}$ extended Brdicka's work and found that arginine, $\beta$-phenyl- $\alpha$-alanine, $\beta$-phenyl- $\beta$-alanine, tryptophane, and histidine exert a suppressive influence on the cysteine wave, and that $\beta$-phenyl- $\beta$-alanine alone in the buffer solution with

\footnotetext{
1 R. Brdicka, Collection Czechoslov. Chem. Commun. 5, 112 and 148 (1933); Biochem. Z. 272, 104 (1933).

2 R. Brdicka, Collection Czechoslov. Chem. Commun. 5, 238 (1933); Mikrochemie 15, 167 (1934).

C. Tropp, Klin. Wochschr. 17, 465 and 1141 (1938).

4 R. Brdicka, Collection Czechoslov. Chem. Commun. 9, 76 (1937)

$6 \mathrm{~J}$. Sladek and M. Lipschutz, Collection Czechoslov. Chem. Commun. 6, 487 (1934).
} 
bivalent cobalt evokes a less pronounced catalytic maximum somewhat resembling that of cysteine, although occurring at a different potential. These results are of particular importance in showing what substances may interfere in the polarographic determination of cystine in hydrolysates which contain other amino acids.

Some protein molecules contain methionine, $\mathrm{CH}_{3}-\mathrm{S}_{-} \mathrm{CH}_{2}-\mathrm{CH}_{2}$ $\mathrm{CH}\left(\mathrm{NH}_{2}\right)-\mathrm{COOH}$, which like cysteine, $\mathrm{H}-\mathrm{S}-\mathrm{CH}_{2}-\mathrm{CH}\left(\mathrm{NH}_{2}\right) \mathrm{COOH}$, is a naturally occurring sulfur-containing amino acid. For the proper interpretation of polarographic determinations of cysteine in certain hydrolysates, it is thus necessary to know whether methionine exhibits a current-voltage wave and/or exerts an effect on the cysteine wave. To obtain this information, polarograms were taken of cystine alone, methionine alone, and cystine together with methionine, in buffered solutions containing bivalent cobalt. Polarograms of djenkolic acid, $\mathrm{CH}_{2}\left(\mathrm{~S}-\mathrm{CH}_{2}-\mathrm{CH}\left(\mathrm{NH}_{2}\right)-\mathrm{COOH}\right)_{2}$, and benzylcysteine, $\mathrm{C}_{6} \mathrm{H}_{5}$ $\mathrm{CH}_{2}-\mathrm{S}-\mathrm{CH}_{2}-\mathrm{CH}\left(\mathrm{NH}_{2}\right)-\mathrm{COOH}$, both of which are related to cysteine, were also taken in the same way, because the former has been isolated from the naturally-occurring djenkol bean ${ }^{6}$ and the latter, in contrast to methionine, can be readily split to form cysteine.

\section{APPARATUS AND MATERIALS}

The polarograph used was the type VIII instrument made by the firm of V. \& J. Nejedly, Prague, Czechoslovakia, for the automatic photographing of current-voltage curves. The galvanometer had a sensitivity of about $3 \times 10^{-9} \mathrm{amp} / \mathrm{mm}$ at a meter distance, which could be varied suitably by means of a calibrated shunt. A sensitivity of 1/200 of full galvanometer sensitivity was used for all the curves shown in this paper.

The cystine was a commercial product (Eastman Kodak Co.) and was not submitted to further purification.

$d l$-Methionine was prepared by the reduction of homocystine with sodium in liquid ammonia, followed by treatment with methyl iodide in the liquid ammonia solution. ${ }^{7}$ It was found by treatment with sodium cyanide and sodium nitroprusside to be free from disulfide. Benzyl-l-cysteine was made from cystine by a similar procedure, using benzyl chloride in place of methyl iodide. ${ }^{8}$ It was likewise shown to be free from disulfide. Both the methionine and benzylcysteine were prepared by W. I. Patterson, Research Associate of the Textile Foundation at this Bureau.

Djenkolic acid, which also had been prepared from cystine by a similar method, using methylene chloride instead of benzyl chloride, ${ }^{9}$ was kindly supplied for this work by Vincent du Vigneaud of the Cornell University Medical School, New York, N. Y.

\section{EXPERIMENTAL RESULTS}

The solutions for measurement were prepared by mixing solutions of the constituents in 25-ml Erlenmeyer flasks, in the order and amount shown in table 1. As soon as each solution was prepared, it was poured into a cell and its polarogram taken, starting at a potential difference of $0.8 \mathrm{v}$ between the dropping mercury cathode and the

6 A. J. Hijman and A. G. van Veen, Geneeskund. Tijdschr. Nederland.-Indï̈ 76, 840 (1936).

7 V. du Vigneaud, H. M. Dyer, and J. Harmon, J. Biol. Chem. 101, 719 (1933).

8 V. du Vigneaud, L. F. Audrieth, and H. S. Loring, J. Am. Chem. Soc. 52,4500 (1930).

v. du Vigneaud and W. I. Patterson, J. Biol. Chem. 114, 533 (1936). 
anode pool of mercury and ending at a little more than $2.0 \mathrm{v}$. The results with solutions 1,2 , and 3 are shown in figure 1 , in which the curve for cystine is labelled $C$, for djenkolic acid, $D$, and for methionine, $M$. Aside from their different effects on the cobalt maximum, which appears between 1 and $1.2 \mathrm{v}$, neither djenkolic acid nor

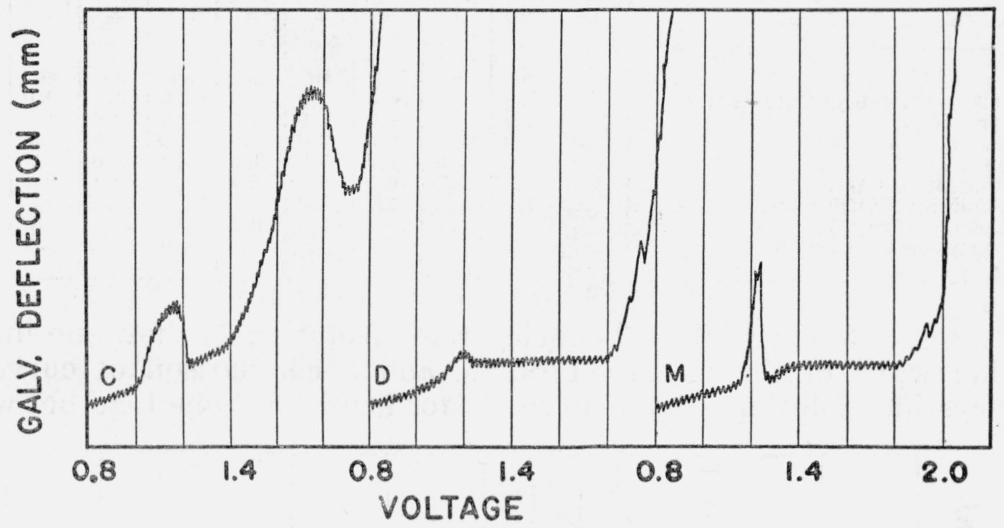

FIgURe 1.-Cysteine $(C)$, djenkolic acid $(D)$, methionine $(M)$.

methionine produces a wave in the range of the cysteine wave. In figure 2, curve $C$ is for cystine alone (solution 4), $C D$ is for cystine together with djenkolic acid (solution 5), and $C M$ for cystine together with methionine (solution 6). The cystine was at the same concentration $\left(2 \times 10^{-5} M\right)$ in each solution. It is seen that djenkolic acid not only depresses the cobalt maximum but also depresses the cysteine

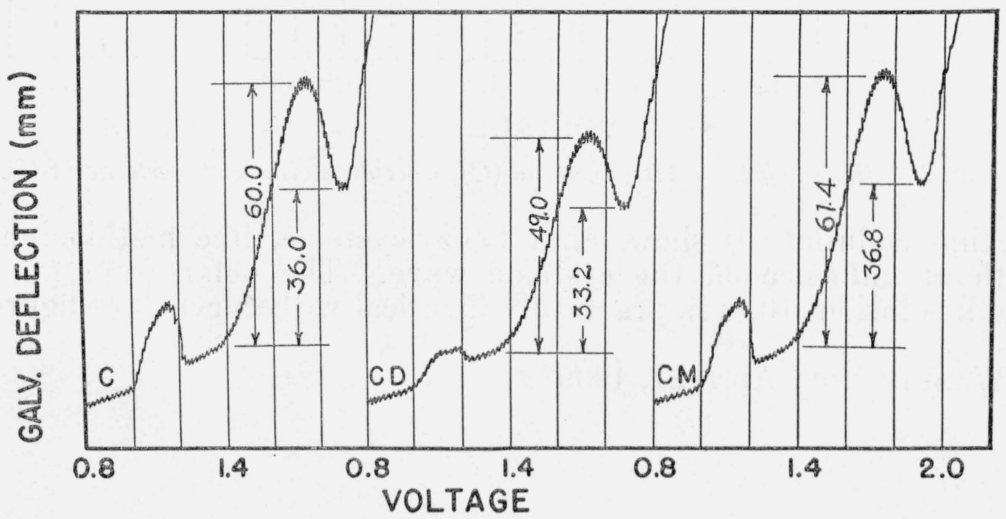

FIGURE 2.-Cysteine $(C)$, cysteine with djenkolic acid $(C D)$, cysteine with methionine $(C M)$.

wave without affecting its shape or position. This behavior was confirmed by repeating the measurements with new solutions. Methionine, however, has no effect on the cysteine wave at these concentrations even though its concentration $\left(5 \times 10^{-5} M\right)$ exceeds that of the cystine $\left(2 \times 10^{-5} M\right){ }^{10} \quad$ Thus, it seems justifiable to conclude that

10 After this work had been completed, similar results with methionine and cystine were reported by Adolf Stern, Eliot F. Beach, and Icie G. Macy at the Ninety-Seventh Meeting of The American Chemical Society at Baltimore, Md. (April 1939). 
the polarographic estimation of cystine at large dilutions is unaffected by the presence of methionine at concentrations up to somewhat more than twice that of cystine.

TABLE 1.-Preparation of solutions

\begin{tabular}{|c|c|c|c|c|c|c|c|c|c|c|}
\hline Solution.- & 1 & 2 & 3 & 4 & 5 & 6 & 7 & 8 & 9 & 10 \\
\hline $\begin{array}{l}\text { Cobaltous chloride }\left(0.8 \times 10^{-3} M\right) \\
\text { Water } \\
\text { Ammonium chloride }(0.5 N) \\
\text { Ammonia }(1 N) \\
\text { Cystine }\left(5 \times 10^{-4} M\right) \\
\text { Djenkolic acid }\left(5 \times 10^{-4} M\right) \\
\text { Methionine }\left(10^{-3} M\right) \\
\text { Benzylcysteine }\left(5 \times 10^{-4} M\right)^{-4}\end{array}$ & $\begin{array}{l}m l \\
4.0 \\
2.6 \\
2.0 \\
1.0 \\
0.4 \\
-1 .-\end{array}$ & \begin{tabular}{l}
$m l$ \\
4.0 \\
2.0 \\
2.0 \\
1.0 \\
\hdashline 1.0 \\
$-1 .-$
\end{tabular} & $\begin{array}{l}m l \\
4.0 \\
2.5 \\
2.0 \\
1.0 \\
-1.5 \\
0.5\end{array}$ & $\begin{array}{c}m l \\
4.0 \\
2.6 \\
2.0 \\
1.0 \\
0.4 \\
-\end{array}$ & \begin{tabular}{l|}
$m l$ \\
4.0 \\
1.6 \\
2.0 \\
1.0 \\
0.4 \\
1.0 \\
-
\end{tabular} & \begin{tabular}{l|}
$m l$ \\
4.0 \\
2.1 \\
2.0 \\
1.0 \\
0.4 \\
0.5 \\
0.0
\end{tabular} & \begin{tabular}{l}
$m l$ \\
4.0 \\
2.0 \\
2.0 \\
1.0 \\
$-1 .-$ \\
\hdashline 1.0
\end{tabular} & \begin{tabular}{l}
$m l$ \\
4.0 \\
2.6 \\
2.0 \\
1.0 \\
0.4 \\
\hdashline- \\
\hdashline-2
\end{tabular} & $\begin{array}{l}m l \\
4.0 \\
1.6 \\
2.0 \\
1.0 \\
0.4 \\
-1.0\end{array}$ & \begin{tabular}{c}
$m l$ \\
4.0 \\
3.0 \\
2.0 \\
1.0 \\
\hdashline- \\
\\
\hdashline
\end{tabular} \\
\hline
\end{tabular}

In figure 3, curve $B$ for benzylcysteine (solution 7 ) shows no interfering wave in the measured range, and a comparison of curve $C$ for cystine (solution 8 ) and curve $B C$ for benzylcysteine together with

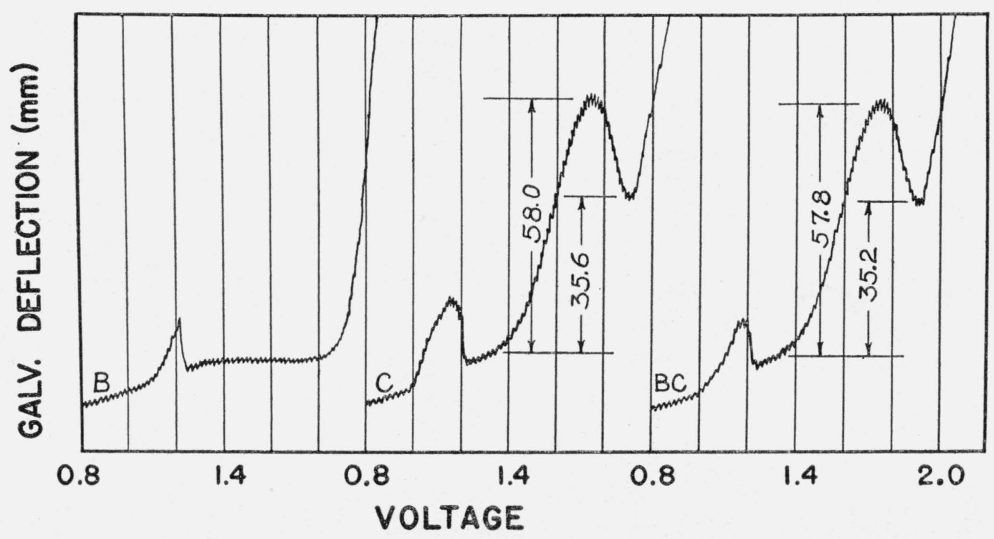

FIGURE 3.-Benzylcysteine $(B)$, cysteine $(C)$, benzylcysteine with cysteine $(B C)$.

cystine (solution 9) shows that benzylcysteine, like methionine, is without influence on the cysteine wave. The polarogram for the blank solution, 10, was practically identical with curve $B$ of figure 3 .

Washington, April 21, 1939. 